\title{
View on Human in the Ukrainian Philosophical Studies in the Interwar Period: from Past to Future
}

\author{
Vitali Turenko \\ Ph.D., Junior Research Fellow, Taras Shevchenko National University of Kyiv \\ (Kyiv, Ukraine) \\ E-mail: vitali_turenko@ukr.net \\ https://orcid.org/0000-0003-0572-9119
}

The article highlights the specifics and features of the formation of philosophical and anthropological studies in Soviet Ukraine. The author focuses on the scientific work carried out during the interwar period (1918-1939) and focuses on the work of such Ukrainian thinkers as Mykola Khvylovyi and Volodymyr Yurynets. It 's proved that before to the emergence of the H.Skovoroda Institute of Philosophy of the National Academy of Sciences of Ukraine and the restoration of the Faculty of Philosophy of Kyiv State University, the works of Ukrianian philosophers of the 20-30's focus mainly on the "deological" factor of human being and formation conception "communist person". Accordingly, Volodymyr Yurynets introduced the concept of "living person", which opposed the ideologized "class person" as such, which is limited in creativity and intellectual activity. Another thinker - Mykola Khvylovyi introduces in his work the concept of "public man", which Ukrainian scientist characterizes as an image of a free, European personality. Finnaly, the author examines the relevance of the introduced concepts by the Ukrainian Soviet thinkers in the context of modern transformations in the understanding of the person.

Keywords: Ukrainian philosophy in Soviet period, human, person, history of Ukraninan philosophy, Mykola Khvylovyi, Volodymyr Yurinets, public person, living person, Marxist-Leninist ideology

Received: September 3, 2019; accepted: October 12, 2019

Future Human Image, Volume 12, 2019: 115-120.

https://doi.org/10.29202/fhi/12/10

\section{Introduction}

The philosophical thought of the Soviet era in Ukraine is a rather ambiguous phenomenon for research. This is due to the fact that the works of this period were largely ideologized by the ruling Soviet authorities, but the scientific works of Ukrainian Soviet philosophers became the basis for research in our time, when independence was already gained. Therefore, to reject them at all is a rather contradictory position. Because of this, the Soviet philosophical heritage needs to be rethought and analyzed in order to understand the true meaning of its significance for the development of Ukrainian philosophy. One such area of philosophical knowledge that has been quite active in this period is undoubtedly philosophical anthropology.

(C) Turenko, Vitali, 2019 
It is worth noting that when it comes to philosophical and anthropological studies in Soviet Ukraine, most of the events of the late 1960s and early 1970s, when the Kyiv School of Anthropology was founded (Volodymyr Shynkaruk). Whereas the studies before this period are actually bypassed by the researchers. However, it should be noted that scientific works Gennadii Vdovychenko (2017), Natalia Galan (2015), Ganna Gushpyt-Titarenko (2013), Anatoliy Loy (2003), Yana Lytvyn (2015) became the theoretical and methodological basis of our research.

Accordingly, the purpose of this article make historical and philosophical reconstruction of the formation anthropological studies in Ukraine in the interwar period.

\section{Specificity view on human in the Ukrainian anthropological studies in the interwar period}

As is known, in scientific studies the idea of differentiating in this period of the history of the Ukrainian philosophy of concepts such as "Soviet philosophy", "Ukrainian Soviet philosophy" and "Foreign Ukrainian philosophy" is proved. Such gradation is conditioned by the political orientation of philosophical thinking. In particular, if Soviet thinkers generally focused their attention on the justification of the legality of the basic postulates of Marxism, then Ukrainian Soviet thinkers within the framework of the Marxist- Leninist paradigm sought ways to resolve national-cultural issues in the specific Ukrainian cognitive key and foreign Ukrainian thinkers tried to form an ideologically impartial approach to the problem of the Ukrainian national question [Galan, 2015: 4].

At the same time, it must be emphasized that "the paradox of dogmatic Marxism, within which the Soviet philosophy functioned, was the fact that he denied that within a worldview he could symbolically be associated with deep value parameters social self-organization. Thus, when all, ideology, the worldview itself, and most importantly people, became hostages of revolutionary, political expediency" [Loy, 2003: 47].

Accordingly, philosophical studies in general and anthropological in particular took place in this context.

Applying a number of criteria, namely [Galan, 2015: 7]:

a) the distinction between the concept of the philosophic personality of the thinker and his scientific product (text);

b) awareness of the ambiguity of the concept "Ukrainian Soviet philosopher", which consists of the integration of the actual philosophical, socio-political and nationalcultural elements;

c) a correct definition of the term "ideological orientations", which served the representatives of the philosophical Soviet discourse of Ukraine in the 20 s and early 30 s of the twentieth century;

d) objectively structured methodology, Natalia Galan observes that it is possible to distinguish the three group of Ukrainian Soviet thinkers of this period: professional philosophers, political figures and journalists, writers and artists.

It should be noted that the key discussion between the then philosophers in the Soviet Union as a whole, and in particular, in the Ukrainian SSR, was the discussion between "philosophersdialectics" and "philosophers-mechanics." The first group included those thinkers focus were methodological problems of natural science, while the second - the professional philosophers 
led by one of the leading philosophers of this period Academician of the USSR (Soviet Union) Abram Deborin. This discussion had an influence also on philosophical and anthropological issues.

In particular, Abram Deborin in one of the works notes the following:

The essence of culture at its present stage (under the prevailing conditions of the working class) is reduced to the deliberate and systematic construction of socialism, in the sense of the development of productive forces, which have the goal of conquering the nature by man, and in the sense of a change of nature of people, we stand in the face of the need to create a new person...All our institutions have to be fitted in order to "shape" the characters of people in the appropriate communist spirit, it is necessary to establish the communist worldview and the concepts and ideas corresponding to it...A new culture based on atheism, materialism and communism can only be built by overcoming and processing the old culture - the whole amount of knowledge and skills that we have inherited from the bourgeois system...The cultural revolution is inextricably linked with the industrial and technological revolution, which forms part of the cultural revolution that is perceived in the broadest sense of the word. As we progress through technical progress, we will, of course, also rise up in a cultural sense. The new socialist technique will create material conditions for the development of a new psychological type, a new man, who will be alien to all the vices inherent in a man of the capitalist era [Deborin, 1927: 14].

At the same time, in the Ukrainian SSR special significance in the context of philosophical and anthropological issues was studied by Mykola Khvylovyi. As Gennadii Vdovychenko emphasizes:

The philosophical and anthropological issues are important for his two cycles $Q u o$ Vadis and Thoughts against the current (1925). It is in these works that philosophical anthropology is represented by such a key element as the concept of "public person". The Ukrainian researcher writes: "For the first time formed in the form of a polysemantic, ambiguous dilemma "Europe" or "Prosvita" in the second section of the first and sixth sections of the second Letters to the literary youth of the Quo Vadis cycle, this concept is detailed in the sections "Psychological Europe" and "Cultural epigonism" the cycle Thoughts against the current. He is mentioned also in the the cycle The Apologists of Scribbling (1926) and consistently conducted in historiosophical considerations of Mykola Khvylovyi in the first, second, sixth and seventh chapters of the cycle "Ukraine or Little Russia?" We draw the distinction between Ukrainian, Russian and German national philosophical traditions, represented by such leading actors of influence on the corresponding system of Mykola Khvylovyi: Marxism and the "philosophy of life" in the German tradition; Russian revolutionary-democratic thought and MarxismLeninism [Vdovychenko, 2005: 74].

As we see, there is a certain confrontation between the Ukrainian and Soviet thinkers. Accordingly, if Soviet philosophers propagated the ideas of the "new person", then Ukrainian philosophers talked on "public person", which in fact is not associated in any way with communist ideals and Marxist-Leninist ideology. Mykola Khvylovyi writes on this: "This 
classical type we conceive in the permanent intellectual, volitional, etc. dynamics...This is a European intellectual in the best sense of the word...The classical type of social person is made by the West. As an add-on, he influenced the economic basis, the well-being of the feudal lords and the bourgeoisie. It will also affect the well-being of the proletariat" [Khvylovyi, 1990: 468-469].

The follower of Mykola Khvylovyi was already a representative of the academic philosophy of the time, namely Volodymyr Yurynets. Gennadii Vdovychenko writes: "Undoubtedly, under the influence of Khvylovyi's cultural philosophy, first of all the directions of its literary and artistic component, Volodymyr Yurynets creatively learned the foundations of its philosophical and anthropological component, namely the concept "psychological Europe". This doctrine of the "classical type of European public person" he used very fruitfully when considering the place and role of writing in Ukrainian and foreign, primarily European, cultural upbringing" [Vdovychenko, 2017: 233].

However, Volodymyr Yurynets speaks not only of "public person", but of "living person." "In fact, Volodymyr Yurynets contrasted the Soviet Union's official propaganda, in particular with the Soviet art and literary criticism, in the form of a "class person", the humanistic ideal of a "living person", a completely different type from the Stalin's visions of a fully developed, qualitatively new, socialist society. An anti-totalitarian humanistic vision of "the type of man of the future" — the "free worker" with his "constructive psychology", which "will work" at the highest level without pressure from above, was carried out with a red thread (through a number of publications -V.T.) creative forces", perceiving work only as a "necessary instinct". Considering this type of person as a "free worker of a classless society", deprived of any exploitation of the full and deliberate creator of a new socialist civil society, he acknowledged his appearance under the condition of the historical progress of the proletariat" [Vdovychenko, 2017: 247].

However, here one must also say about the anthropological collision, which has already happened not only on the pages of books, but in the very life of Volodymyr Yurynets. Undoubtedly, the result was a totalitarian influence on the intellectual elite of that time, the pressure of which this Ukrainian thinker could not resist. Thus, "participating in the beginning of 1926 Politburo of the Central Committee of the $\mathrm{CP}(\mathrm{b})$ in the campaign of public critique and condemnation of Mykola Khvylovyi as the author of the Ukrainian version of the "anti-Marxist and anti-Leninist theory of the struggle of two cultures", Volodymyr Yurynets condemned in the article (On the occasion our literary discussion // Ways of development of the Ukrainian proletarian literature, Literary discussion (1925-1928), Collection of materials - Kharkiv: Ukrainian Worker, 1928. - pp. 185-193 - V.T.) developed by him in cycles pamphlets Quo Vadis, Thoughts against the current and The Apologists of Scribbling: the doctrine of "public person", the concept of "Asian renaissance", theory of proletarian art - and proclaimed exclusiveness Russian vector of social and cultural life of the USSR" [Vdovychenko, 2017: $150]$.

As the consequence of this ambiguous event in the context of the philosophical and anthropological perspective, and others in the Ukranian intellectual life, "in the course of the 1930-1940s philosophical thought in Soviet Ukraine is stopped. As Ganna Gupshit-Titarenko notes, continues to have an official philosophy, which was taught in the articles of "The Bolshevik" magazine (after the XIX Congress of the Communist Party — "Communist"). Myroslav Popovych in his writings draws attention to the existence of strict rules for writing such documents. However the almost total extermination of philosophers, which was carried 
out during the previous years, gradually begins to be made in the light of the needs of the functioning of a totalitarian state system" [Gushpyt-Titarenko, 2013: 118-119].

Consequently, in concluding analysis this period in the history of Ukrainian philosophy, it can be noted that the studios on philosophical and anthropological issues were rather small in scope. Works in this philosophical branch took place within the framework of an ideological discussion for the creation of a "new", "communist person". Instead, it was the Ukrainian Soviet intellectuals who proposed the concept of "public person" (Mykola Khvylovyi) and "living person" (Volodymyr Yurynets).

\section{New image of human: view on future}

As you can see, although Ukrainian scientists were created under the conditions of a totalitarian regime and severe censorship, they were still capable of developing quite original concepts, including and in understanding the essence and purpose of human life. What is important is that the works of Volodymyr Yurents and Mykola Khvylovyi do not appear to be "on the shelf". They are quite relevant in our time as well, when we see powerful scientific and technological progress that is trying to change radically the essence of human existence and interpersonal relationships.

Right now, the main thing is not so much live, real, existing, as virtual, what is online. A person imbued with electronics, technical means so much that it can actually be said that his life is completely embedded in the screen (phone, TV or other technical device) from conception to death. Person Man seems to become more "alive", "public", but in fact, as modern thinkers, it becomes more and more lonely. After all, you can virtually create an image of a person who is pleasing to others and does not particularly feel problems in communication, relationships (friendly or intimate). And it will continue to grow in different volumes and qualities. Eventually, it is predicted in the future that person will largely be replaced by artificial intelligence.

Accordingly, the problem arises and the task is not to lose "living", "authenticity", the reality of human life and coexistence with other individuals. Nothing will replace true living human communication, no matter how new technologies are created or implemented. Because of this, we can see how relevant and important are the concepts of "public person" Mykola Khvylovyi and "living man" Volodymyr Yurents.

\section{Conclusions}

Thus, having made a historical and philosophical reconstruction of the formation anthropological studies in the interwar period, we can draw the following conclusion that scientific researchers were carried out within the framework of the discussion and the program of forming a "new", "communist" person. Within the Ukrainian Soviet philosophy, their own concepts of understanding the essence and purpose of human existence were offered. In particular, Mykola Khvylovyi introduced the concept of "public person", and Volodymyr Yurinets "a living person". However, since such kind of manifestations of philosophical thought was not subordinated to the dominant Marxist-Leninist ideology, their existence in subsequent Soviet philosophical studies was nullified. 


\section{[ㅁ] References}

Deborin, Abram. Marxism and culture, Revolution and culture, 1927, №1: 8-16.

Galan, Natalia. Philosophical-critical discourse in the theoretical heritage of Ukrainian Soviet philosophers of the 1920s - 1930s: PhD-theses 09.00.05, Kyiv, Dragomanov National Pedagogical University, 2015.

Gushpyt-Titarenko, Ganna. Existential anthropological and personal orientation of Ukrainian philosophy of the second half of the twentieth century, Scientific Bulletin of Chernivtsi University. Philosophy, 2013, 646-647: 118-122.

Khvylovyi, Mykola. Works in 2 volumes. V.2. Kyiv, Dnipro, 1990

Loy, Anatoliy. Philosophy and Worldview in Late Marxism, Philosophical and Anthropological Studies. Kyiv: Stylos, 2003: 103-130.

Vdovychenko, Georgiy. Philosophy of history and philosophical anthropology of $\mathrm{M}$. Khvylovyi, Multiversum. Philosophical almanac, 50, 2005: 74-82.

Vdovychenko. Georgiy. Philosophy of Culture as a Direction of Philosophical Thought of Ukraine of the 20-30's of the 20 th Century (Historical and philosophical analysis). PostDoc in Philosophy: 09.000.05. Kyiv, 2017. 